\title{
20 Years of Performance Measurement System (PMS) Implementation in Indonesian Local Governments: Why is Their Performance Still Poor?
}

\author{
Hafiez Sofyani*, Rusdi Akbar and Rodiel C. Ferrer
}

\begin{abstract}
Manuscript type: Research paper.

Research aims: This study aims to investigate the Performance Measurement System implementation in Indonesian local governments and the phenomenon of institutional isomorphism.

Design/ Methodology/ Approach: This paper employed a qualitative approach, using semi-structured interviews and observations. The samples comprise the heads of departments and individuals representing the agencies and institutions in the Yogyakarta Special Region. A deductive thematic method was utilised as the data analysis technique.

Research findings: The study reveals that institutional isomorphism is still in existence. It plays a dominant role in the Performance Measurement System (PMS) implementation of Indonesian local governments at the coercive level. This situation leads to the underachievement of the successful PMS implementation.

Theoretical contributions/ Originality: This paper fulfills an identified need for studying how institutional isomorphism influences PMS implementation. This area of study is underresearched in the public sector of accounting, particularly in Indonesia.
\end{abstract}

* Corresponding author: Hafiez Sofyani is a Lecturer at the Department of Accounting, Universitas Muhammadiyah Yogyakarta, Indonesia. Email: hafiez.sofyani@umy.ac.id

Rusdi Akbar is an Associate Professor at the Department of Accounting Universitas Gadjah Mada, Yogyakarta, Indonesia. Email: rusdi.akbar@ugm.ac.id

Rodiel C. Ferrer is a Professor at the Department of Accountancy, De La Salle University, Manila, Philippines. Email: rodiel.ferrer@dlsu.edu.ph

Acknowledgment: This research was funded by the University of Norway in collaboration with Universitas Gadjah Mada, Indonesia, in a research grant scheme "In Search of Balance". 
Practitioner/ Policy implications: The results of this study show that there is a need for the government or authorities to focus more on understanding how institutional isomorphism at the coercive level may lead to poor PMS implementation. The authorities also need to improve the condition by emphasising on normative isomorphism which can address the problems caused by limited information system, budgetary, human resources and difficulties in determining performance measures.

Research limitation: This study is limited to the Yogyakarta Special Region province thus findings cannot be generalised while the approach used is confined to the qualitative method only. This may also affect the outcome of the findings to some extent.

Keywords: Local Government, Institutional Isomorphism, Performance Measurement System, Public Sector Accounting.

JEL Classification: G11, G02, C91

\section{Introduction}

Performance Measurement Systems (PMS) is an area of interest in organisational studies. It is the process of collecting, analysing and reporting information about the performance of the organisation to see if what has been achieved is the same as what was intended or should have been achieved. The technique that is to be used to measure the performance of the public sector, nonetheless, was not discussed until 1993 when the United States developed a series of laws which led to the enactment of the Government Performance and Results Act, the GPRA, 1993 (Ittner, Lacker, \& Randall, 2003; Atkinson, Waterhouse, \& Wells, 1997; Sofyani \& Akbar, 2013). The GPRA 1993 requires all agencies to participate in the performance management tasks which involve setting goals, measuring results and reporting on progress. As a developing country, Indonesia only began to introduce the PMS to its public institutions a little later, through the issuance of the Presidential Instruction (PI) No. 7 1999. The PI was issued as a consequence of the governance reform, moving from the New Order Era which is said to be corrupted, non-transparent and non-unaccountable, to the Reform Era which emphasises on better governance, responsibility, transparency, and accountability. Through the Reform Era, the PMS implementation is perceived to be more advanced and of good governance (Sofyani \& Akbar, 2013).

Previous studies (Jurnali \& Siti-Nabiha, 2015; Sihaloho \& Halim, 2005) have highlighted the importance of the PMS as a key component 
of public sector management. The PMS is said to help organisations to develop integration between strategic planning, target formulation and measurement and reward and punishment (De Araújo, Branco, \& Francisco, 2009). Despite the significant role of the PMS, its implementation in Indonesia has not achieved the full aim of improving performance and accountability. According to Jurnali and Siti-Nabiha (2015), the assessment of local public institutions and agencies by the central government has demonstrated poor results. In 2013, only 24 per cent of the districts and cities in Indonesia had achieved good rankings after 14 years of PMS implementation. A more recent data on the performance of accountability reporting was extracted from the Ministry of Administrative Bureaucratic Reform of Indonesia. Data revealed that in 2016, only 12 per cent of local governments in Indonesia had obtained predicates A (excellent), BB (very good) and B (good) for their performance. Meanwhile, 83 per cent of the data had attained predicates CC (more than fairly good), C (fairly good) and D (poor) in their performance.

Sihaloho and Halim (2005) mentioned that most government agencies that implement the PMS are commonly subjected to external pressures due to coercive and mimetic isomorphisms. Undoubtedly, this could cause agencies to display fake obedience (Gudono, 2014). A situation of this nature can cause the PMS implementation to fail or to lead to poor performance of the PMS among local government agencies and institutions (Akbar, Robyn, \& Brian, 2012; Sofyani \& Akbar, 2013). While institutional isomorphism has been suggested to be the source of disappointing results, its role and level of existence in Indonesian local public agencies and institutions is still less researched. Previous works (Berry, Coad, Harris, Otley, \& Stringer, 2009; Akbar et al., 2012) related to PMS had mostly used the institutional theory to provide some insights but these were limited in scope. Theoretically, the enactment of the PI No. 7 1999, as proposed by the Indonesian government, was considered to be mimetic isomorphism, when viewed from the perspective of institutional isomorphism. The PI No. 71999 was the government's effort to imitate another more "superior" institution in governance for its mechanism of actions, in this case, the United States' GPR Act of 1993 (Gudono, 2014). The Act made it imperative for the Indonesian government to implement it on its respective institutions. The aim was to enable these institutions to gain insight into how institutional isomorphism may influence successful PMS implementation. 
Previous studies (e.g., Julnes \& Holzer, 2001; Ittner et al., 2003; Cavalluzzo \& Ittner, 2004; Nurkhamid, 2008; Speklé \& Verbeeten, 2014; Wijaya \& Akbar, 2013; Sofyani \& Akbar, 2013) which examined the factors impacting the effectiveness of PMS had been dominated by the quantitative approach, mainly using surveys to collect data. Despite its advantages, the approach also offers risk of partiality because respondents tend to answer the questionnaire normatively or even carelessly, ignoring what would have been reality.

The current study aims to explore the phenomenon of institutional isomorphism in the PMS implementation of local governments in Indonesia. It also aims to look at the effectiveness of the PMS execution. This study extends on the previous research of Sofyani and Akbar (2013) by employing a qualitative research technique. Previously, Sofyani and Akbar (2013) had studied the relationship between training, performance measures, information system limitations, decision-making authority and incentive, and PMS implementation. Their findings indicated that only the training variable had some association with the PMS implementation. Thus, additional explorations are necessary in order to gauge how other variables influence the PMS implementation of local governments. A qualitative approach comprising observations and interviews is thus deemed to be suitable in the context of this study (Kristiantoro, Basuki, \& Fanani, 2018). This is because exploring the phenomena in a realitistic world can help to capture the underlying reasons not usually stated in surveys.

The findings of this study expands on the literature of institutional isomorphism, particularly from the Indonesian perspective. This study is believed to carry important implications for government authorities who are compelled to develop a more comprehensive and effective strategy for the successful implementation of the PMS in Indonesian local governments.

The rest of this paper is organised as follows. Section 2 reviews the literature on institutional isomorphism and performance measurement system. Section 3 explains the methodology employed. Section 4 discusses the findings and Section 5 concludes the paper.

\section{Literature Review and Focus of the Study}

\subsection{Institutional Isomorphism}

Institutional isomorphism is a concept that is used to explain the homogeneity of organisations in the same field. DiMaggio and Powell 
(2000) mentioned that organisations in the same field tend to be alike due to isomorphism caused by imitation or independent development. Isomorphism is more influential on the institution itself than customer demands or market power. Isomorphism has shown that when organisations reach an established level, they tend to move toward uniformity. This is why the best term to describe the process of "uniformity" is "isomorphism". Studies (e.g. Akbar et al., 2012) showed that organisational structures and processes tend to become uniform (isomorphic) and this is characterised by certain acceptable norms for certain types of organisations. The condition can lead to the emergence of certain organisational behaviour to become legitimised. For example, Tolbert and Zucker (1983) found that from time to time, civil service reforms are adopted because it is symbolic of good governance rather than because of efficient goals.

According to Meyer (1979), Fennell (1980) and DiMaggio and Powell (2000), there are two types of isomorphism: competitive and institutional. Competitive isomorphism emphasises the rationality assumption of market competition whereas institutional isomorphism explains that organisations compete not just for resources and customers but also for the power of political legitimacy and institutional, economic and social conformity. Institutional isomorphism is a useful tool to be used to understand the politics and procedures of modern organisational life. It is an equally useful tool for organisations where politics and the culture of "ceremonial and formal administration" are embedded into the organisational environment (e.g., in the local government of Indonesia).

DiMaggio and Powell (2000) further suggested three different mechanisms through which isomorphism occurs. These mechanisms can be described as coercive, mimetic or normative. Coercive isomorphism occurs as a result of pressures exerted by other external parties, upon which the organisation is dependent on for some reason. The pressure can be felt as a force, a persuasion, or an invitation, for instance, to join collusions. Gudono (2014) explained that coercive isomorphism refers to the process where an organisation uses specific features due to the impact caused by coercion or pressure from the state, other organisations or the community. A typical example is when strict regulatory or legal requirements are imposed on companies, requiring them to conform to certain operational standards. Mimetic isomorphism occurs when organisations imitate other organisations that are perceived as having a successful track record. The imitation can occur through the 
sharing of information among employees or through recommendations from consulting firms or industry associations. In some cases, the adoption of "innovation" that aims to improve the legitimacy is applied so as to show other organisations that they are also trying to improve working conditions. DiMaggio and Powell (2000) gave examples of how the Japanese corporate management style is imitated by companies from other countries because it is deemed to be successful. Finally, normative isomorphism occurs when organisations naturally conform to the context of their industry as a result of their normal business practices. Normative isomorphism is derived from two important sources: formal education and legitimacy. These two elements are noted in the cognitive skills of the professionals produced by university experts. In other words, normative isomorphism is the growth and spread of a professional network that forms the organisation (Larson, 1977; Collins, 1979; DiMaggio \& Powell, 2000).

Pacheco, York, Dean, and Sarasvathy (2010) stated that the three institutional isomorphisms can also be graded according to levels. The highest level is normative isomorphism which occurs when organisations have embedded certain practices into their cultural norms, customs and artefacts. The intermediate level is mimetic isomorphism which occurs due to pressure. At the fundamental level is coercice isomorphism where the rules of the game are defined by institutionalism.

Turning their attention to the civil service, Tolbert and Zucker (1983) found that over time, the reforms of the civil service has became pillars of good governance while the purposes of efficiency has been disregarded. These reforms then become a form of political legitimacy where it is seen by the government to have concerns for good governance. This occurs because the government has adopted a mechanism based on legal pressure or coercion from higher institutions and not by normative consciousness from organisations to implement the policies. Based on the explanation by Tolbert and Zucker (1983), it would appear that the isomorphic phenomenon in the PMS implementation of Indonesian local governments, whether based on achieving the organisations' objectives or imitating the patterns of other institutions, needs to be reviewed. Doing so will help to illustrate whether or not the isomorphic phenomenon is functioning legitimately or whether it signals that the public (stakeholders) and the Indonesian local government are following the new public management concept (Akbar, Robyn, \& Brian, 2015). From this perspective, the logic of change 
in PMS that is institutionalised into the organisation can be perceived through three mechanisms: coercive, mimetic or normative (Scott, 1998; DiMaggio \& Powell, 2000). These mechanisms will then indicate whether isomorphism occurred partially or coherently or through trigger or as a triggered object (Sofyani \& Akbar, 2013).

\subsection{Implementation of Performance Measurement System and Isomorphism in Indonesia}

PMS implementation in Indonesia began from the issuance of the PI No. 7 of 1999, as mentioned earlier. This instruction has also mandated the implementation of the Government Performance Accountability Report (GPAR) on all Indonesian local governments. The GPAR report carries a comparison result showing what the original plan was and what the actual results had achieved. This report helps the government agencies to determine their performance on a quantitative scale (number or percentage). The benefits of preparing the GPAR include: (1) increasing the accountability of agencies, (2) providing information that is useful for feedback, (3) improving planning in all fields for both programmes or activities and the organisation's resources, (4) improving the agency's credibility in the eyes of a higher institution and ultimately, improve public trust, (5) identifying and assessing the success or failure of the agency in carrying out the duties and responsibilities of the agency and (6) ensuring that government agencies are transparent and accountable in carrying out the common tasks of the government and development.

Although the Indonesian local governments have already implemented the PMS for about 20 years, its implementation scale has not achieved the aims of performance improvement. According to the 2016 report (see Table 1) posted on the website of the Ministry of Administrative and Bureaucratic Reform (MABR), 16 out of 34 provincial governments had obtained a CC-rated performance and one had even obtained a D performance. Only two provincial governments had achieved A performance with 15 obtaining B and BB predicates. The two provincial governments were from the Special Region of Yogyakarta and East Java. At the regency and city level, 83 per cent or 425 of the institutions had obtained ratings of C, CC and D. In general, the MABR minister had considered the performance of the local governments (regency and city level) in Indonesia to be at the $C$ predicate still. The table indicates that Yogyakarta achieved the highest predicate while North Borneo achieved the lowest predicate. 
Table 1: Performance Score of Provincial Government $2016^{1}$

\begin{tabular}{rlcc}
\hline \multicolumn{1}{c}{ No. } & \multicolumn{1}{c}{ Provincial Governments of Indonesia } & Predicate \\
\hline 1 & Daerah Istimewa Yogyakarta / Special Region of Yogyakarta & 80.68 & $\mathrm{~A}$ \\
2 & Jawa Timur / East Java & 80.04 & $\mathrm{~A}$ \\
3 & Kalimantan Selatan / South Borneo & 76.30 & $\mathrm{BB}$ \\
4 & Bali / Bali & 75.39 & $\mathrm{BB}$ \\
5 & Kalimantan Timur / East Borneo & 75.15 & $\mathrm{BB}$ \\
6 & Sumatera Selatan / South Sumatera & 75.11 & $\mathrm{BB}$ \\
7 & Jawa Tengah / Central Java & 72.09 & $\mathrm{BB}$ \\
8 & Sumatera Barat / West Sumatera & 70.52 & $\mathrm{BB}$ \\
9 & Jawa Barat / West Java & 70.06 & $\mathrm{BB}$ \\
10 & Kepulauan Riau / Riau Archipelago & 68.62 & $\mathrm{~B}$ \\
11 & Bengkulu / Bengkulu & 63.74 & $\mathrm{~B}$ \\
12 & Nusa Tenggara Timur / East Nusa Tenggara & 62.42 & $\mathrm{~B}$ \\
13 & Sulawesi Utara / North Sulawesi & 61.00 & $\mathrm{~B}$ \\
14 & Bangka Belitung / Bangka Belitung & 60.96 & $\mathrm{~B}$ \\
15 & Kalimantan Barat / West Borneo & 60.85 & $\mathrm{~B}$ \\
16 & Sulawesi Tenggara / Southeast Sulawesi & 60.85 & $\mathrm{~B}$ \\
17 & Kalteng / Central Borneo & 60.69 & $\mathrm{~B}$ \\
18 & Daerah Khusus Ibu Kota Jakarta / Jakarta Capital City & 58.57 & $\mathrm{CC}$ \\
19 & Nusa Tenggara Barat / West Nusa Tenggara & 58.56 & $\mathrm{CC}$ \\
20 & Aceh / Aceh & 58.24 & $\mathrm{CC}$ \\
21 & Sumatera Utara / North Sumatera & 58.00 & $\mathrm{CC}$ \\
22 & Sulawesi Selatan / South Sulawesi & 56.25 & $\mathrm{CC}$ \\
23 & Maluku / Maluku & 55.62 & $\mathrm{CC}$ \\
24 & Gorontalo / Gorontalo & 55.15 & $\mathrm{CC}$ \\
25 & Riau / Riau & 54.73 & $\mathrm{CC}$ \\
26 & Jambi / Jambi & 52.87 & $\mathrm{CC}$ \\
27 & Lampung / Lampung & 51.13 & $\mathrm{CC}$ \\
28 & Banten / Banten & 51.12 & $\mathrm{CC}$ \\
29 & Sulawesi Tengah / Central Sulawesi & 50.56 & $\mathrm{CC}$ \\
30 & Sulawesi Barat / West Sulawesi & 50.23 & $\mathrm{CC}$ \\
31 & Papua / Papua & 46.03 & $\mathrm{C}$ \\
32 & Papua Barat / West Papua & 32.81 & $\mathrm{C}$ \\
33 & Malaku Utara / North Maluku & 31.24 & $\mathrm{C}$ \\
34 & Kalimantan Utara / North Borneo & 25.34 & $\mathrm{D}$ \\
\hline & & &
\end{tabular}

Source: Ministry of Administrative and Bureaucratic Reform (MABR), (2016).

\footnotetext{
${ }^{1}$ In Indonesia there are 2 (two) levels of local government as a form of regional autonomy, namely the local government level 1 (provincial government) and government level 2 (regency/city government). The performance of local governments evaluated by the Ministry of Administrative and Bureaucratic Reform (MABR) includes both of them. The ranking or predicate of local government performance issued by MABR is AA (excellent), BB (Very Good), B (Good), CC (More than Fairly Good), C (Fairly Good), D (Poor).
} 
Table 2: Aspects of Assessment by MABR

\begin{tabular}{|c|c|c|c|}
\hline No. & Aspects & Weightage (\%) & Components Evaluated \\
\hline 1 & Planning & 35 & $\begin{array}{l}\text { Strategic Planning } \\
\text { Performance Planning } \\
\text { Determination of Performance } \\
\text { Alignment between Subcomponents }\end{array}$ \\
\hline 2 & $\begin{array}{l}\text { Performance } \\
\text { Measurement }\end{array}$ & 20 & $\begin{array}{l}\text { General Performance Indicators } \\
\text { Key Performance Indicators } \\
\text { Measurement } \\
\text { Performance Measurement Analysis }\end{array}$ \\
\hline 3 & $\begin{array}{l}\text { Performance } \\
\text { Reporting }\end{array}$ & 15 & $\begin{array}{l}\text { Reporting Compliance } \\
\text { Disclosure and Presentation } \\
\text { Utilisation of Performance Information }\end{array}$ \\
\hline 4 & $\begin{array}{l}\text { Performance } \\
\text { Evaluation }\end{array}$ & 10 & $\begin{array}{l}\text { Implementation of Performance Evaluation } \\
\text { Utilisation of Evaluation Results }\end{array}$ \\
\hline 5 & $\begin{array}{l}\text { Performance } \\
\text { Achievement }\end{array}$ & 20 & $\begin{array}{l}\text { Achievement of Performance } \\
\text { Determination } \\
\text { Achievement of Targets } \\
\text { Reliability of Data } \\
\text { Alignment with Achievement of Develop- } \\
\text { ment Targets in Planning Documents }\end{array}$ \\
\hline
\end{tabular}

According to the Regulation of the Minister of Administrative and Bureaucratic Reform No. 13/2010 which focussed on the Guidance for Evaluation of Accountability Performance of Governmental Institution, the MABR had conducted the assessment based on aspects depicted in Table 2.

As can be seen in Table 1, the PMS implementation at different levels of the Indonesian local governments is still facing problems that are related to the five assessment aspects set by the MABR. It is assumed that one of the major setbacks is due to the practice of imitating the PMS implementation of more advanced countries. This is also known as mimetic isomorphism. Although mimetic isomorphism is the result of mimicking other organisations because of the good practices and values, mimetic isomorphism also carries adverse effects. For instance, improvement tends to get stuck at the implementation phase. This happens because the implementation is ceremonial in form and not oriented on the substance (Tolbert \& Zucker, 1983). The adverse effect 
is especially more obvious if the implementers fail to understand the substance of the policy. In line with this, Sihaloho and Halim (2005) observed that the majority of government agencies which consistently follow the PMS formulated by the Financial Supervisory Agency and the Institute of Public Administration, tend to be dominated by external pressures. This is recognised as coercive isomorphism (Tolbert \& Zucker, 1983). Such pressures often raise false compliances (Gudono, 2014). Another setback is the conflict of interest where most agencies are motivated towards meeting or complying with the requirements of the central government and not the public services (Akbar et al., 2012).

Adapting institutional theory in their study, Akbar et al. (2012) also found that organisations compete with each other for political power and institutional legitimacy. Wijaya and Akbar (2013) focussed on the impact of information, objectives and organisational goals and external pressures against the PMS adoption. They found that PMS implementation is influenced by information and pressure by other parties. In their study, Sofyani and Akbar (2013) categorised the factors which impacted the PMS implementation of agencies into technical and organisational factors. The technical factors include the difficulty of agencies to determine performance measures and the limitation of the information system. Organisational factors include decision-making authority, training and incentives. Their study also demonstrated that training is the only factor that is related to the PMS implementation. Therefore, it is imperative to use the qualitative approach to explore why other variables may not play a substantial role in the PMS implementation. Following Sofyani and Akbar (2013), this study attempts to understand how the technical and organisational factors are relevant to the PMS implementation of Indonesian local governments in the Special Region of Yogyakarta.

\subsubsection{Technical Factors}

Difficulty to Determine Performance Measures and Information System Limitations

According to the Government Accountability Office (Gates, 1999), the multiple overlapping objectives of public organisations in Indonesia is one of the factors which could potentially hinder successful PMS implementation. This is because it is difficult for organisations to evaluate the policies, programmes and activities which have been implemented 
for various purposes. Another reason is because the information systems that are employed in implementing the PMS is limited. The limitations of the information system is restrained by its reliability, completeness, timeliness in data acquisition and validity of the data produced (Cavalluzzo \& Ittner, 2004). These conditions may trigger imitations from other institutions that are facing similar demands in the PMS implementation. This condition encourages the emergence of mimetic isomorphism (Tolbert \& Zucker, 1983; DiMaggio \& Powell, 2000). Other situations representing normative isomorphism or coercive isomorphism may also occur because the conditions on the organisations are uncertain and unpredictable. Based on the above arguments, the statement of the problem to be investigated is deliberated as:

RQ1: How do the local government organisations cope with information system limitations and difficulties in determining the performance measures? What is the isomorphism phenomenon that occured?

The answer to this question will be discussed in the following subsection.

\subsubsection{Organisational Factors}

\section{Decision-making Authority}

As heads of organisations, managers are granted the authority to make decisions. This authority enables them to determine the conditions and methods of work procedure as well as to develop and legitimise the autonomy of their work, with the aim of fostering professionalism (Larson, 1977; Collins, 1979; DiMaggio \& Powell, 2000). This practice of professionalism that is developed within an organisation is an indication that there are plans to manage the organisation in accordance with expected normative rules. Hence, professionalism is associated with the isomorphism perspective. The presence of authority in decision making will probably lead to the phenomenon of normative isomorphism (Gudono, 2014). However, the greater authority of managers can create potential barriers in increasing the accountability of government organisations. This happens when the law, the bureaucratic rules, or the separation of powers between the organisational units of the local government increases the limit of authority for decision making by managers (Cavalluzzo \& Ittner, 2004). Undobtedly, the 
increased decision-making authority will hinder the onset of normative isomorphism thereby leading to mimetic isomorphism or coercive isomorphism.

\section{Training}

Focussing on government institutions, Nurkhamid (2008) stated that training could serve as an opportunity for employees to understand, accept, and be well versed with the innovation of their institutions. Training can also be an opportunity to reduce employees' stress on the need to implement the innovation. The training in question, among others, include the preparation of performance reports and strategic planning, the preparation of the working plans of the government, the defining and development of the performance target and the indicators of a programme, and evaluating the implementation of the agencies' objectives. Such trainings, it is argued, may have a positive impact on the government employees into implementing a particular policy. This is even more applicable to those employees who are in charge of the PMS implementation of their organisations. Based on the institutional isomorphism theory, it can be said that training can be a driving factor for the emergence of normative isomorphism (Larson, 1977; Collins, 1979; DiMaggio \& Powell, 2000; Gudono, 2014).

\section{Incentive}

Incentives drive motivations and the key to motivate people into performing what is expected by an organisation is to connect their organisational achievements to organisational incentives that are related to their individual goals. This can propel the individuals to have stronger motivations especially when their actions generate a potential reward. In this regard, it is advisable to have a reward-oriented management control system (Anthony \& Govindarajan, 2004). Another perspective is offered by Simons (2000) who proposed that there are two ways to encourage people to work in accordance with the objectives of the organisation. First, when people believe the ultimate goal of the organisation can be achieved (so there is more effort to achieve it), and second, when the management draws the employee's attention to the objectives to be achieved through formal incentives (reward or payment). The result of the incentive policy is in line with the PMS implementation and this can enhance professionalism. This is a form of normative isomorphism (March \& Olsen, 1976; Larson, 1977; Collins, 1979). 
Based on the above arguments, the objects of observation included in the organisational factors are decision-making authority, training and incentives. Each of these carry different implications. Trainings that are directly related to professionalism will probably lead to normative isomorphism. As said earlier, organisational professionalism is an indication of the organisation's plan to adhere to normative rules (Larson, 1977; Collins, 1979; Gudono, 2014). However, decisionmaking authority and incentives will probably lead to the emergence of a different phenomenon of isomorphism. Therefore, in studying the isomorphism phenomenon of organisational factors, it is necessary to explore what actually happens, from a neutral and objective point of view. Based on this, the formulation of the problem to be investigated is as follows:

RQ2: How did the local government run the PMS? What kind of isomorphism phenomenon is related to the decision-making authority, training and incentives?

\section{Methodology}

\subsection{Research Approach and Model}

Extending on the empirical works of Sofyani and Akbar (2013), this study uses a qualitative approach to collect and analyse data based on thematic interpretations. Since Sofyani and Akbar (2013) had failed to establish the relationship between performance measures, information system limitations, decision-making authority and incentives with the PMS implementation, the current study aims to address the gap by exploring why these variables did not influence the PMS implementation of the Indonesian local governments. A semi-structured interview approach was used to collect data. This approach allows the interviewer to have some control on the interview whilst giving the interviewees some space to present their views in more detail (Eriksson \& Kovalainen, 2008; Ahyaruddin \& Akbar, 2017).

The respondents were selected through a purposive sampling technique because this approach emphasises on individuals who are available, willing to be interviewed and possess the knowledge needed (Nagy Hesse-Biber \& Leavy, 2011). An invitation to participate in the study were sent through email. The respondents were informed about the study, its purpose, and the type of information that will be sought. Respondents who expressed interests to participate were contacted 
to arrange a convenient time, and were provided with a copy of an interview guide. Each interview lasted between one to two hours and was audio-recorded. The interviews were conducted in the Indonesian language and done at the respondents' workplace.

They were assured that the information they provided would be used only for research purposes, and that anonymity of their names and particulars would be maintained. The recorded data were then transcribed using verbatim. The interview guide shown in Table 3

Table 3: Interview Guidance

\begin{tabular}{lll}
\hline Factors & Variables & Exploratory question \\
\hline & $\begin{array}{l}\text { Limitation of } \\
\text { Information } \\
\text { System }\end{array}$ & $\begin{array}{l}\text { 1. What obstacles are often faced by } \\
\text { local government units in PMS } \\
\text { implementation? }\end{array}$ \\
$\begin{array}{lll}\text { 2. What intervention is done in the face } \\
\text { of information system limitations? }\end{array}$ \\
\cline { 2 - 3 } Technical & $\begin{array}{l}\text { Difficulty in } \\
\text { determining } \\
\text { performance } \\
\text { measurement }\end{array}$ & $\begin{array}{l}\text { 1. How difficult is it to determine } \\
\text { appropriate performance measure? }\end{array}$ \\
& $\begin{array}{l}\text { Decision-Making } \\
\text { Authority }\end{array}$ & $\begin{array}{l}\text { 1. Is there any authority in the formula- } \\
\text { tion and implementation of PMS? }\end{array}$ \\
& $\begin{array}{l}\text { 2. What are the visible effects of } \\
\text { granting authority in PMS }\end{array}$ \\
& implementation?
\end{tabular}

2 The incentives referred to in this study are monetary rewards that are given to local government employees to support the PMS implementation. 


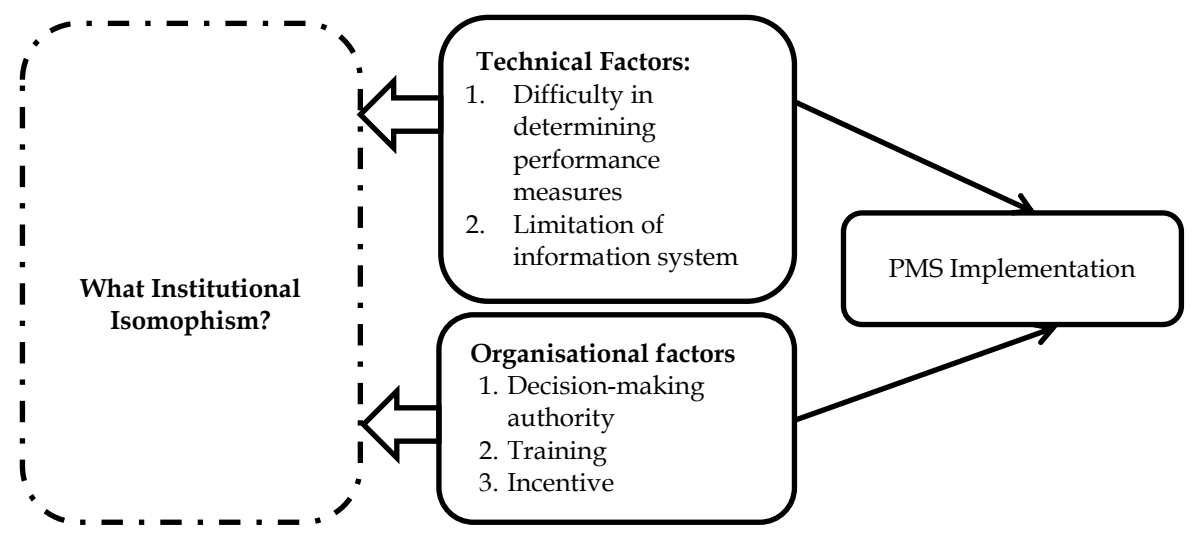

Figure 1: Research Framework

was adopted from Koh, Mohan, and Tan (2015) and Yaya (2017). The research framework used is illustrated in Figure 1. Observations were also conducted on the organisational structure, especially the functions related to PMS implementation, performance reporting, and the relationship of the PMS implementation with other governance activities, specifically those that relate to planning and budgeting. At the observation stage, the researchers examined whether the organisational structure of the local government unit is in accordance with the needs of the PMS implementation and also whether the parties (capabilities and the number of employee) involved were ideal or not, as stated in the Presidential Instruction No. 7 1999. The researchers also examined the completeness of the performance report and its preparation process by assessing the PMS flow chart as well as the transparency of its reporting to the public. Finally, the researchers examined how the performance report was used in relation to planning and budget formulation and the evaluation of strategic plans of the local government. As can be noted, the interview questions were extended to the interviewees according to the desired factors. Figure 1 illustrates the theoretical framework which is based on organisational theories of institutional isomorphism.

\subsection{Respondents' Profiles}

The respondents for this study comprised individuals who were attached to the local government agencies and institutions in the Special Region of Yogyakarta. These respondents were responsible for the 
respective units hence they were generally, heads of the units such as Head (Sleman Regency), Head of Planning Department (Yokyakarta City, Special Region of Yogyakarta Province, Bantul and Kulon Progo Regency), Head of Administration (Gunung Kidul) in the local government unit. In total there were six respondents. Their details are presented in Table 4.

Table 4: Codification of Interviewees

\begin{tabular}{lllc}
\hline Code & Detail & Degree & Experience \\
\hline \#YP & Respondent from Yogyakarta Special & Master & 8 years \\
& Region & Master & 12 years \\
\#YK & Respondent from Yogyakarta City & Bachelor & 21 years \\
\#SL & Respondent from Sleman Regency & Doctorate & 25 years \\
\#BL & Respondent from Bantul Regency & Bachelor & 13 years \\
\#KP & Respondent from Kulon Progo Regency & Bachelor & 15 years \\
\#GK & Respondent from Gunung Kidul Regency & Bach & \\
\hline
\end{tabular}

It appears that the respondents were fairly experienced in their position, with a minium of eight years and a maximum of 25 years. The mean for their total years of work experience is 15.66 years, which is quite an impressive length of experience.

\subsection{Data Analysis Technique}

Data were analysed using the thematic deductive analysis approach based on Braun and Clarke (2006). As a qualitative analytical method, it identifies, analyses and reports a pattern or theme that is contained in the data. The steps taken in this study encompass coding the data, categorising the data, identifying the main idea and grouping them into themes until a general pattern of tendency emerged from the data. Aronson (1994) had also mentioned that thematic analysis focuses on themes and patterns. Professional linguists (translator) were also consulted when transcriptions were translated into English, to ensure that the research data are communicated clearly.

To ensure the reliability and validity of the data collected, three members of the research team first read each transcript independently, and created a preliminary list of salient and noteworthy respondents' quotes; and identified the reflected themes from the data. The identified 
codes and themes then, were reviewed and discussed among the team members. The aim is to formalise on an agreed upon code list. Next, final coding of the data was done independently by the team members and compared. During this process, particular attention was paid to themes marked by recurrence, repetition and emphasis. Coding and analysis were facilitated by the qualitative data software, verbatim. All three members reached agreement on final themes, which remained stable and consistent across all the semi-structured interviews conducted. Data were then summarised and grouped into conceptual themes.

\section{Research Findings}

\subsection{Technical Factors and Institutional Isomorphism}

\subsubsection{Information System Limitations}

Based on the analysis, it was established that civil servants do not face issues using the information systems employed by their units to support the PMS implementation (\#KP, \#GK, \#YK, \#BL, \#YP and \#SL). This is because the implementation of the PMS in several local government units which included the determination of performance indicators, data collection and reporting were still done manually. As stated by respondent \#KP:

PMS implementation in this unit is still manual. But Bappeda (Local Government's Planning Board) of Kulon Progo regency are designing and holding preparatory steps of PMS Implementation, including performance reporting, which are based on Information System. (\#KP)

Respondent \#SL also mentioned:

... for the overall PMS implementation including performance rating ... are still done manually.... Automation is still unimplemented. (\#SL)

This finding is very interesting. It tells us that after almost 20 years of introducing the PMS, the local governments in the Yogyakarta region are still running it manually. To further understand the phenomenon, we asked our interviewees, "How to improve the process of determining the performance indicators and reporting?" One of the respondents (\#GK) explained that since the implementation of the PMS is a strategic move, the head of the regency needs to ensure that 
the implementation of the PMS and the reporting is done regularly and executed according to the prevailing regulations. The strategic aspect mentioned here is that PMS and the performance report is one of the information that was highlighted by the respondents. It seems to be influenced by the electability of the Head of the Regency. As stated by \#GK:

... although the PMS implementation in here is still manual, we are still required to implement PMS and report the performance of agencies in accordance with applicable law. It is always emphasised by the Head of the Regency. (\#GK)

\subsubsection{Difficulty to Determine Performance Measurement}

Based on the observations, it was found that the PMS implementation was not done en masse nor was it done systemically. It appears to be handled by two or three local government officers (\#BL, \#GK and \#KP) only. In reality, the PMS implementation should be an integral mechanism where all the local government officers in the respective units should be conducting it together. It also appears that the numerous duties encompassing: (1) budgeting, (2) planning of the work programme, (3) executing the planned programme, (4) running the administration, and (5) preparing the financial statements were each handled by different officers. This suggests that there could be a lack of synchronicity. However, as many agencies had focussed on the timeliness and compliance of budgetary targets and financial statement requirements, only those officials who were affected were engaged in the PMS implementation. These results confirm the findings of Wijaya and Akbar (2013) who noted that the number of local government units implementing the PMS were negatively impacted by the pressure from higher authorities (in this case the central government). Evidence for this is traced to the following responses.

... PMS implementation, especially the performance reporting is done by two to three employees, including me, and my colleagues. While, ideally everyone should be involved. That is because our work requires a lot of time, so our main focus is achieving our targets and deadlines rather than performance reporting.... (\#BL)

In here, specifically in formulating of work plans and reporting of performance accountability, almost all of them were done by me 
.... Because I also have many works, so I ask 2-3 new employees to help me. (\#GK)

... for the performance report, everything about it, is done by a special team consisting of three employess here.... (\#KP)

With regards to the problem of determining the performance measurement, the respondents from the Yogyakarta Special Region and Gunung Kidul reported that the constraints pertaining to the technical information systems and the determination of performance measures were already anticipated by the employees at the local government unit. Thus, they would consult academics from universities during the planning and formulation of the performance measurements (\#YP and \#GK). Despite the constraints in the PMS implementation, they had taken steps to adapt thereby developing their cognitive autonomy which in turn, legitimises their work towards professionalism. This phenomenon fueled normative isomorphism as is evident among competent civil servants who implement the PMS. However, there were also local government units which perceived the determinants of performance measurement related to the performance evaluation of local government agencies as a major obstacle. This is supported by respondent \#YK:

The difficulty occurs during creation and identification... it's difficult to formulate, and this is our weakness. Thus, Bappeda/ Local Government's planning in recent years have tried to revise the strategic planning related performance measures to be more scalable and reliable. (\#YK)

Furthermore, the number of tasks and objectives that must be implemented by local government units were numerous. They include strategic planning, determining performance measurements, implementing the PMS, evaluating the performance, reporting and revising the work programme, preparing financial statements and performance reports. These were required by the higher organisation and also regulated by law, as described by the interviewee of Bantul Regency. Respondents were of the opinion that the number of tasks given to local government units were too many and too difficult to manage simultaneously. This had caused the poor performance which is further compounded by the unequal distribution of work structure. For instance, the PMS implementation is assigned to a special team of only two or three members (\#BL, \#GK and \#KP). Besides being 
overwhelming, this structure is not aligned to the full intention that the PMS implementation should involve all employees in the local government unit.

To complete the task that was usually not understood by their colleagues in the same local government units, the majority of respondents (\#SL, \#BL, \#KP, \#GK and \#YK) revealed that they would communicate with employees in other units. Hence mimetic isomorphism was triggered. This situation eventually led to fake observance as described by Gudono (2014). The response of \#KP is illustrated.

... Planning, implementing activities and so on, as well as about the controls in the execution of the work including the absorption of the budget, we are always controlled by the leaders, particularly related to the absorption of budget and performance achievements... if we do not understand we usually discuss with colleagues from other (local government) units.... (\#KP)

Observations in the field also located evidence of other problems that were not defined in the formulation of the research problem. They include difficulty in defining the strategies for achieving predetermined performance indicators. According to the respondents from Kulon Progo, Gunung Kidul and Yokyakarta, the PMS is triggered by a bureaucratic system and administration which is not supported by budgets. This problem leads to the issue of budgets being overspent and unscheduled.

As the representative of one local government, one respondent (\#YK) mentioned that the local government unit was not able to adhere to its budget plan and programme made during the beginning of the year due to inadequate funds. As a result, the implementation of the work programme was delayed and not executed in the latter part of the year. The issue was further burdened by the weak cash management of the agencies (\#KP, \#BL and \#YK). It appears that the availability of funds within local government agencies depend on the realisation of regional revenues. These, in turn, depend on the timeliness of the people paying the taxes and their retribution liabilities. Consequently, it can lead the local government units to overuse their budget massively at the end of the fiscal year without considering the efficiency and usefulness of the expenses. This is supported by respondent \#KP:

... When the activities of a technical nature, in the field we have limited time ... administrative constraints that must be met 
occasionally for one reason or another cannot be completed, causing melting of constrained budgets, so work is also hampered. There is also an impact on the percentage of absorption. Usually it makes problems that often occur technically. (\#KP)

Respondent \#BL also said:

Usually the obstacles that arise relate achievement targets are not entirely met .... (\#BL)

The same issue was also indicated by respondent \#YK:

... In essence achievement is not always in line with budget realisation.... (\#YK)

In the condition described above, the executive local government units usually prioritise accountability reporting rather than the realisation of the programme (\#YK). In other words, the local government units tend to prioritise the completion of the performance report rather than the achievement of the programme implemented. Clearly, this is caused by the pressure of the head of the institution, both on local government units and the central government. The pressures usually emerge in the form of compulsions to local government units to implement the PMS and to accomplish the performance report with an appropriate format and within the delivery time. It seems that this phenomenon had caused the local government units to implement the PMS and the performance reporting rigidly. However, they were merely legitimate attempts made by the respective units to show obeyance. Their obeyance did not lead to the achievement of the targets hence it can be said that the PMS implementation by the government was dominated by coercive isomorphism. This argument is consistent with the findings of Wijaya and Akbar (2013) and Akbar et al. (2015).

\subsection{Organisational Factors and Institutional Isomorphism}

\subsubsection{Decision-Making Authority}

The outcome of this study has shown that one of the barriers in the PMS implementation in local governments was the bureaucratic system that had limited the space/creativity and authority given to civil servants in general (\#YK and \#BL). It was clear that the authority in strategic planning and decision making of policies were held by the top management. As a result of this, the PMS implementation appeared to be stiff and rigid, pursuing only administrative demands. This was 
explained by Akbar et al. (2015) who mentioned that the documents projecting the performance report was actually untouched, once the report was written. This condition suggests that the document was merely stored and not employed as an input material or as information for future policy formulation. The claim was endorsed by Cavalluzzo and Ittner (2004). They argued that the law, rules of the bureaucracy, and the separation of powers between organisational units of government increases the limitations of authority for the decision making of the managers or leaders in local governments. This was also articulated by \#YK:

... The space we have is limited.... We already have the plot of jobs. So we only had to fill that. Our expressions were also limited.... (\#YK)

Meanwhile, the representative of Bantul Regency (\#BL) mentioned that his unit was able to implement the PMS and performance reporting in detail. He asserted that the bureaucratic imposition had limited the creativity of his unit. It also hindered the improvisation which the local government employees could carry out in their roles as employees, especially in relation to the PMS implementation. The respondent from Kulon Progo Regency (\#KP) also supported the comments of the respondent from Bantul Regency (\#BL). They claimed that the PMS implementation was conducted with full authority mainly to fulfil its objectives. However, due to the restrained authority given, the responsibility and the competence of those who should perform those tasks were often not aligned. For example, in the Department of Tourism, Youth and Sports, the head and the subordinate's expertise were not related to the objectives of the department. Nonetheless, the head would still be in charge of implementing the PMS even though he may have no expertise or knowledge. Therefore, if there were ideas proposed for the PMS implementation and these were not favoured by the head, the idea can be dismissed even though it may be good. This can be traced to the comments of respondent \#BL.

... In the PMS implementation and reporting, we have determined who does what by the regulations. Therefore, excessive improvisation is not allowed, even though the goal is for the essence of the implementation of PMS itself.... (\#BL)

This was collaborated by respondent \#KP who stated:

We often find incompatibility of authoritative positions. It constrains ideas that can be used to achieve our targets. If I have any 
idea for a particular activity and my Department Head did not like it, most likely than not, the idea is rejected even though it is a good idea that can help achieve our targets.... (\#KP)

\subsubsection{Training}

The concept of training for employees were perceived by some of the respondents to be beneficial for the PMS implementation (\#GK, \#YP and \#BL). However, they also pointed out that the actual training is merely complementary because training alone was not enough to help in the PMS implementation and PMS reporting. The training became even more important for those who need to implement the PMS but do not have the competencies (\#YK and \#KP). This observation may be related to the lack of training conducted for the local government employees for the PMS implementation. This is evidenced by what the following respondents mentioned:

... Somehow training cannot solve the problem (PMS implementation and PMS reporting). I am an engineer and administration process is my weakness, but my boss took me as head of administration in my agency.... (\#YK)

Respondent \#KP also mentioned:

... The trainings were done once or twice a year. The government is more focused on the implementation of new regulations, the accrual basis in financial reporting, etc.... (\#KP)

\subsubsection{Incentives}

The analysis of data also showed that the local government units in the Special Region of Yogyakarta (Daerah Istimewa YogyakartaDIY) except the Bantul local government, do not impose reward systems such as giving certain incentives as a strategy to stimulate PMS implementation. In the Sleman regency, however, incentives to support the PMS implementation had existed previously. However, the policy was abolished by the Head of the Regency. The interviewees however, do not know the exact reason for the abolition of the policy. It was presumed that this was caused by the absence of a legislative governance (\#GK, \#KP, \#SL and \#YP). In the Provincial Government of Yogyakarta (Special Region) however, these monetary incentives were replaced by morale boosters such as appreciation, attention and 
other intangible rewards. It cannot be denied that the motivation to implement the PMS in accordance with its normative goals is necessary for the local government employees. The claim is supported by some of the interviewees' comments below.

As indicated by respondent \#GK,

Incentives to support PMS and performance reporting do not exist. That is because the practice of PMS and reporting of performance is part of a mandatory civil service duty. The payment is our monthly salary (\#GK)

Respondent \#YP also mentioned,

Monetary incentives do not exist. But, the moral incentives are provided, such as appreciation, attention and other forms of nonmaterial incentives.... (\#YP)

At the organisational level, normative isomorphism appears to be triggered by the training given to employees. Some respondents however, said that the trainings contributed little to the implementation and the reporting of the PMS (\#YK and \#KP). The summary of this study is presented Table 5 .

From the analysis noted from the interviews and observations, it is without doubt that the PMS implementation in the Indonesian local government units of the Special Region of Yogyakarata is very heavily affected by coercive isomorphism. A number of respondents (\#GK, $\# \mathrm{KP}$, and \#YK) had implied that the implementation and reporting of the PMS were caused by the demands of leadership. These demands need to be obliged by the government agencies. The impact of this on the PMS implementation causes agencies to 'model' their organisation after more successful organisations in order to meet the objectives of the law. This argument is in line with the proposition that the issuance of Instruction No. 71999 is the reason why isomorphism is so prevalent in the Indonesian local governments. It is their way of empowering themselves by copying other more advanced countries. Further to that, we also find that the performance report we obtain in this research is also untouched and underutilised. The interviewee from Bantul Regency (\#BL) explained that after the performance report was completed, the documents were stored and rarely referred to. This condition characterises the fact that the PMS implementation is indeed limited to fulfilling the legislative requirements only (Akbar et al., 2015). This implies that the PMS implementation is the result of coercion. 
Performance Measurement System (PMS) Implementation in Indonesian Local Governments

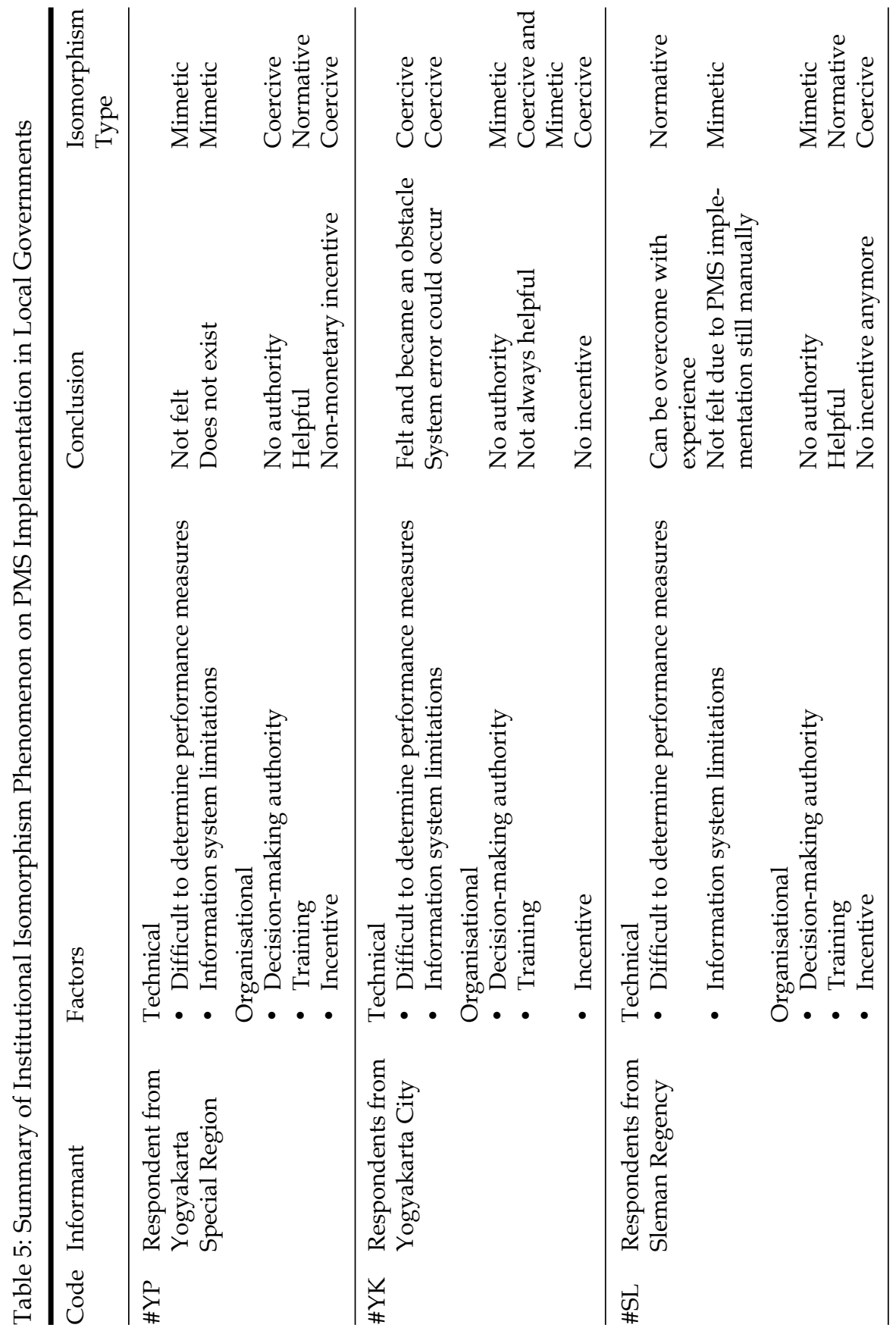


Hafiez Sofyani, Rusdi Akbar and Rodiel C. Ferrer

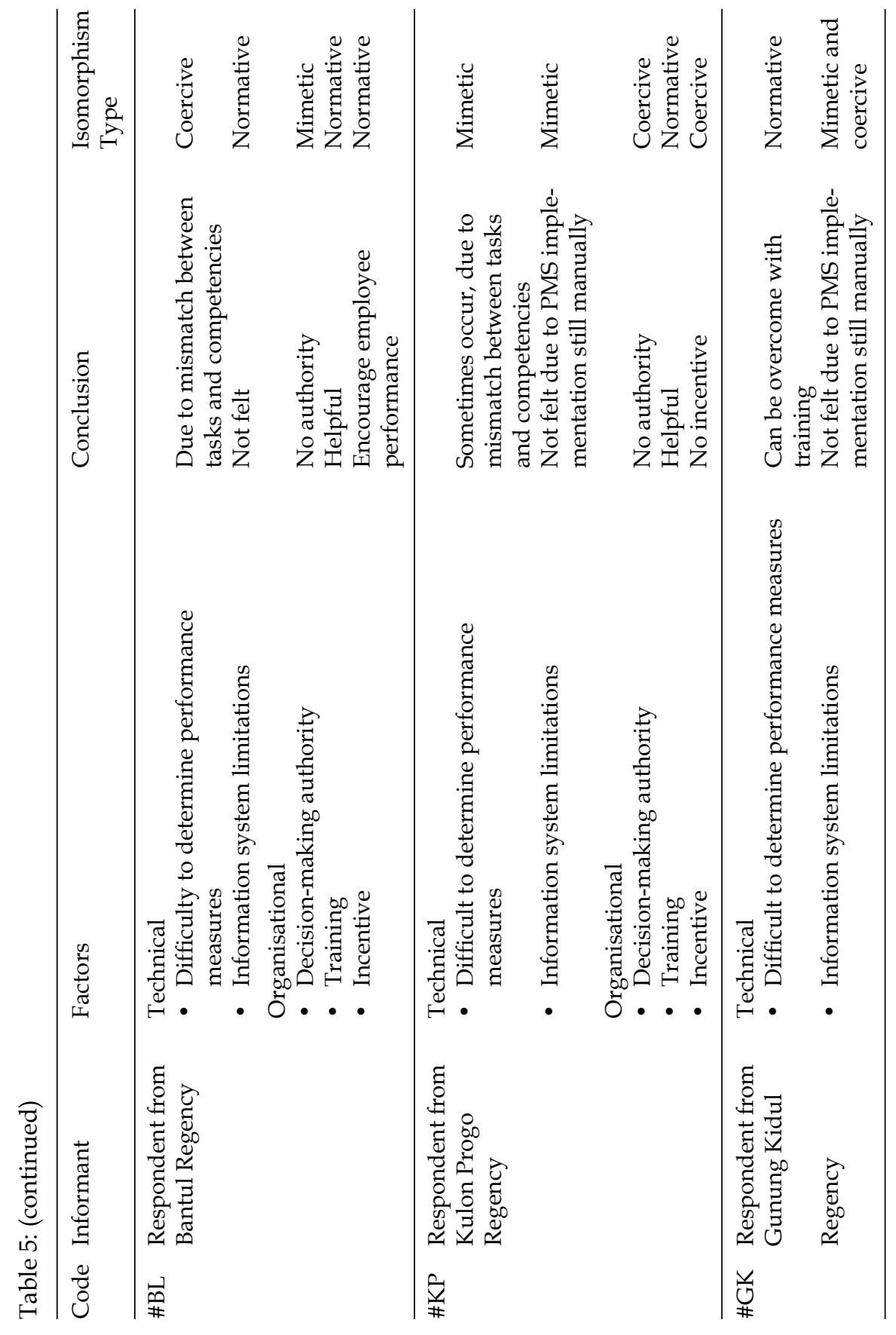


Performance Measurement System (PMS) Implementation in Indonesian Local Governments

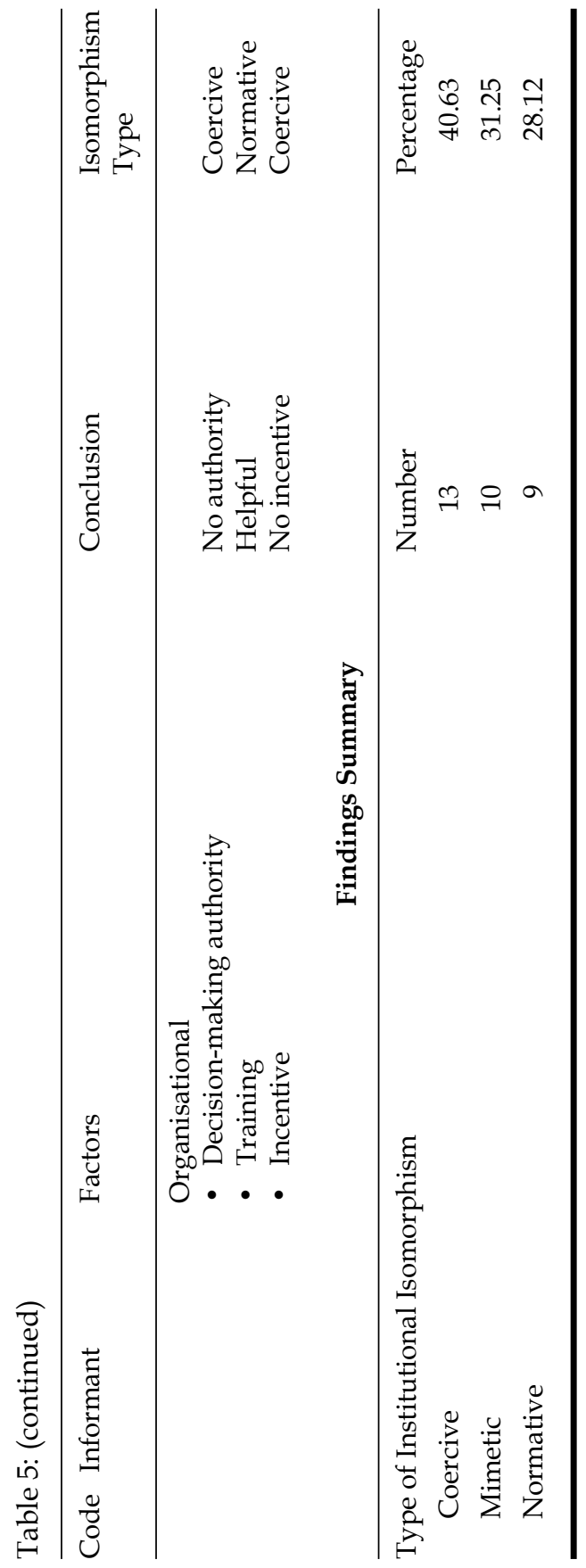


However, in addressing the various obstacles and discrepancies that occurred, some agencies have initiated and sought for the best solution by adapting their knowledge, experience, and capabilities where these are needed. Where there is normative isomorphism, it is deployed not only as a motivating factor but also as a consequence of the constraints faced by agencies such as limitations of information systems, difficulties in determining performance measures, the limitations of budgetary and human resources. Table 6 summarises the isomorphism phenomenon that have occurred in the Indonesian local government agencies.

\section{Conclusion, Implication and Limitation}

This study contributes to the body of knowledge by exploring how institutional isomorphism theory is associated with the PMS implementation of Indonesian local governments. In doing so, this study contributes to the underresearched area of institutional isomorphism in the context of public sector accounting in Indonesia. The importance of this study is further enhanced by the issuance of the Presidential Instruction and the reform of governance drawn from the Reform Era. The study of Sofyani and Akbar (2013) served as the basis of the exploration of the institutional isomorphism phenomenon. In particular, it focussed on technical factors such as information systems limitation and the difficulty of determining the performance measures as well as organisational factors such as decision-making authority, training and incentives. The study conducted by Sofyani and Akbar (2013) was limited to testing the influence of organisational variables toward PMS implementation. This study extends on the study of Sofyani and Akbar (2013) by exploring the PMS implementation from the viewpoint of institutional isomorphism which is further classified as: normative isomorphism, mimetic isomorphism and coercive isomorphism.

From the viewpoint of institutional isomorphism, the findings showed the outcome drawn from each of the factors mentioned above: information systems' limitations, the difficulty of determining the performance measures, decision-making authority, training and incentives. Each of these can trigger either coercive isomorphism, mimetic isomorphism or normative isomorphism. However, the dominance of isomorphism occurring in each of the factors related to the PMS implementation is still at the coercive level. This indicates 
Performance Measurement System (PMS) Implementation in Indonesian Local Governments

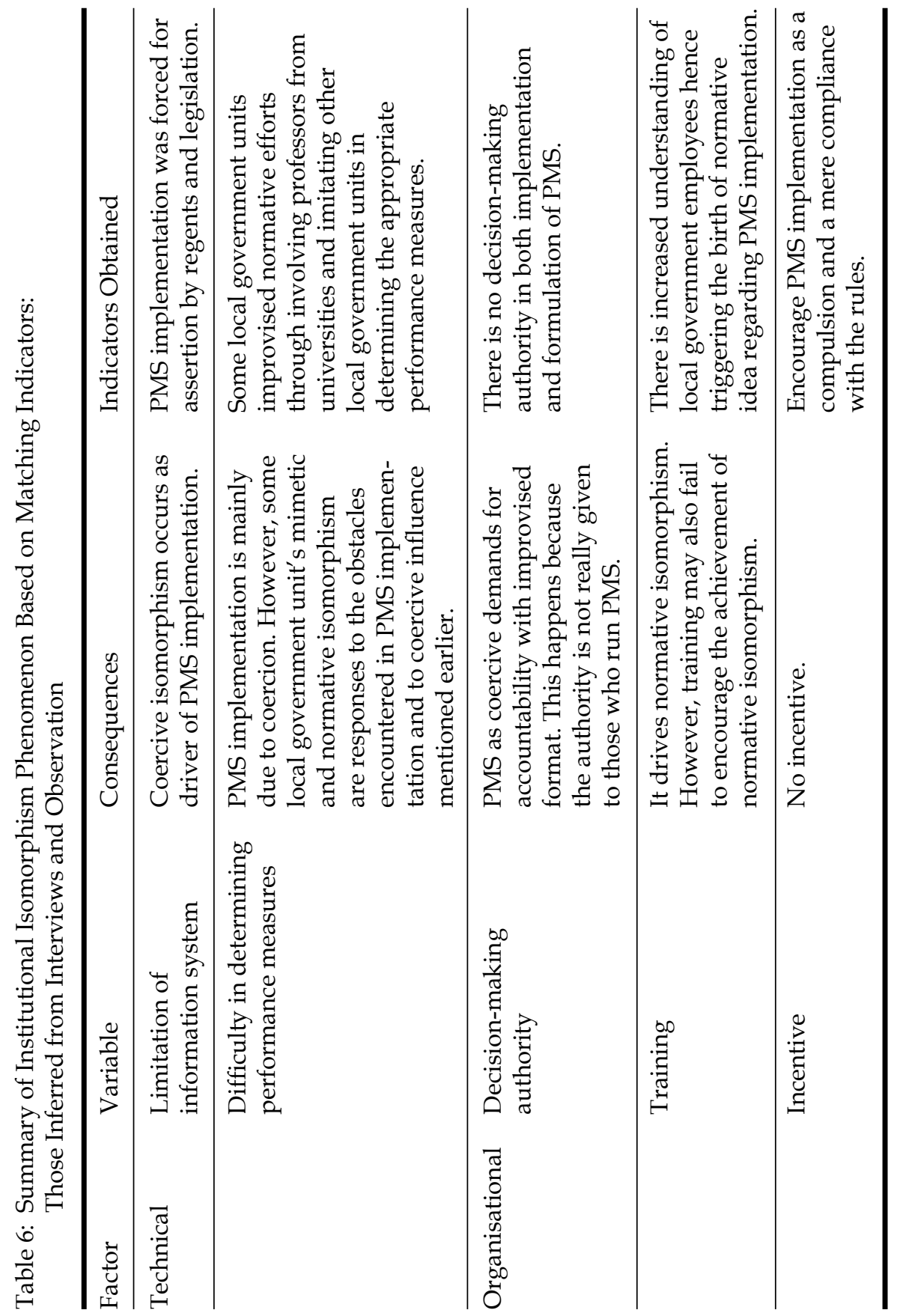


that the PMS implementation in the local governments is still not in accordance with the actual purpose of the PMS itself. As a constitutional government that is decentralised, it is not suprising that the local governments in Indonesia experienced pressures from the central government to report their performance. The existence of such pressures could be due to the fact that most of them were dependent on the financial resources and various acknowledgements of the central government. This situation however, is not an exception since public institutions in the UK are also considering the law as a change factor (Talbot, 2008). While this appears to be a push factor for PMS implementation, this study suggests that the local government should attempt to naturally build the implementation of the PMS through their daily normal practices, thereby pratising normative isomorphism. An important aspect that must be considered is to continuously conduct structured trainings and to provide rewards either monetary or intangibles for PMS implementation. This can motivate employees to be even more committed to their work. Additionaly, providing the minimal level of training to local government officials would also be able to drive normative isomorphism. Among the local governments situated within the Special Region of Yogyakarta, it appears that only the government of Bantul was implementing an incentive system to support the PMS implementation. It is asserted that the absence of an incentive system drives the PMS implementation towards mimetic isomorphism because the execution of the administrative tasks is based purely on performance only.

This study has several limitations that could potentially affect the results. It was confined to the Special Region of Yogyakarta only. Interviews were only performed in six different local government agencies. Since each local government is unique by itself, neither the local governments' PMS implementation practices nor the respondents from those governments, can be used to generalise the practices of other government units and other government employees working on the PMS. The data obtained and analysed were relatively minimal because the researchers were barred from accessing additional data in their efforts to explore the overall status of the PMS implementation in the local governments. This study is confined to the qualitative approach only, hence it is recommended that future studies apply a mixed research method to enable a more in-depth study and evaluation from different points of views. 


\section{References}

Ahyaruddin, M., \& Akbar, R. (2017). Indonesian local government's accountability and performance: The isomorphism institutional perspective. Journal of Accounting and Investment, 18(1), 1-11. http://dx.doi.org/ 10.18196/jai.190187

Akbar, R., Robyn, P., \& Brian, P. (2012). Performance measurement in Indonesia: The case of local government. Pacific Accounting Review, 24(3), 262-291. http://dx. doi.org/10.1108/01140581211283878

Akbar, R., Robyn, P., \& Brian, P. (2015). Implementing performance measurement systems: indonesian local government under pressure. Qualitative Research in Accounting and Management, 12(1), 3-33. http://dx.doi.org/ 10.1108/QRAM-03-2013-0013

Anthony, R.N., \& Govindarajan, V. (2004). Management control system. New York, NY: McGraw-Hill.

Aronson, J. (1994). A pragmatic view of thematic analysis. The Qualitative Report, 2(1), 1-2.

Atkinson, A.A., Waterhouse, J.H., \& Wells, R.B. (1997). A stakeholder approach to strategic performance measurement. Sloan Management Review, 38(3), 25-37.

Berry, A.J., Coad, A.F., Harris, E.P., Otley, D.T., \& Stringer, C. (2009). Emerging themes in management control: A review of recent literature. The British Accounting Review, 41(1), 2-20. http://dx.doi.org/10.1016/j.bar.2008.09.001

Braun, V., \& Clarke,V. (2006). Using thematic analysis in psychology. Qualitative Research in Psychology, 3(2), 77-101. http://dx.doi.org/ 10.1191/ 1478088706qp063oa

Cavalluzzo, K.S., \& Ittner, C.D. (2004). Implementing performance measurement innovations: Evidence from government. Accounting, Organizations and Society, 29(3-4), 243-267. http://dx.doi.org/10.1016/S0361-3682(03) 00013-8

Collins, R. (1979). The credential society: A historical sociology of education and stratification. New York, NY: Academic Press.

De Araújo, J.F.F.E., Branco, A., \& Francisco, J. (2009). Implementing performance-based management in the traditional bureaucracy of Portugal. Public Administration, 87(3), 557-573. http://dx.doi.org/10.1111/j.14679299.2009.01762.x

DiMaggio, P.J., \& Powell, W.W. (2000). The iron cage revisited: Institutional isomorphism and collective rationality in organizational fields. In J.A.C. Baum, \& F. Dobbin (Eds.), Economics meets sociology in strategic management (pp. 143-166). Bingley, UK: Emerald Group Publishing Limited.

Eriksson, P., \& Kovalainen, A. (2008). Qualitative research in business studies. New York, NY: SAGE Publication.

Fennell, M.L. (1980). The effects of environmental characteristics on the structure of hospital clusters. Administrative Science Quarterly, 25(3), 484-510. http://dx. doi.org/10.2307/2392265 
Gates, S. (1999). Aligning strategic performance measures and results. New York, NY: The Conference Board.

Gudono. (2014). Organization theory (3rd Ed.). Yogyakarta: BPFE-Yogyakarta.

Ittner, C.D., Larcker, D.F., \& Randall, T. (2003). Performance implications of strategic performance measurement in financial services firms. Accounting, Organizations and Society, 28(7-8), 715-741. http://dx.doi.org/10.1016/ S0361-3682(03)00033-3

Julnes, P.D.L., \& Holzer, M. (2001). Promoting the utilization of performance measures in public organization: An emprirical study of factors affecting adoption and implementation. Public Administration Review, 61(6), 693-708. http:/ / dx.doi.org/10.1111/0033-3352.00140

Jurnali, T., \& Siti-Nabiha, A.K. (2015). Performance management system for local government: The Indonesian experience. Global Business Review, 16(3), 351-363. http:/ / dx.doi.org/10.1177/0972150915569923

Kristiantoro, H., Basuki, B., \& Fanani, Z. (2017). The institutionalization of spending review in budgeting system in Indonesia. Journal of Accounting and Investment, 18(1), 36-53. http:/ / dx.doi.org/10.18196/jai.190190

Koh, E.H., Mohan, A.V., \& Tan, K.H. (2015). A more comprehensive approach to competency development: An exploratory study on the risk management function of banks. Asian Journal of Business and Accounting, 8(2), 1-24.

Larson, M.S. (1977). The rise of professionalism: A sociological analysis. Berkeley, CA: University of California Press.

March, J.G., \& Olsen, J.P. (1976). Ambiguity and choice in organizations. Bergen, Norway: Universitetsforlaget.

Meyer, J.W. (1979). The impact of the centralization of educational funding and control on state and local organizational governance (Institute for Research on Educational Finance and Governance, Report No. IFG-PR-79-B20). Retrieved from https:/ / files.eric.ed.gov/fulltext/ED202139.pdf

Ministry of Administrative and Bureaucratic Reform (2016). Economic Report on Indonesia. Retrieved from https://www.bi.go.id/en/publikasi/laporantahunan/perekonomian/Pages/LPI_2015.aspx

Nagy Hesse-Biber, S., \& Leavy, P. (2011). The practice of qualitative research: Engaging students in the research process. Thousand Oaks, CA: Sage Publications.

Nurkhamid, M. (2008). Implementasi inovasi sistem pengukuran kinerja instansi pemerintah. Jurnal Akuntansi Pemerintah, 3(1), 45-76.

Pacheco, D.F., York, J.G., Dean, T.J., \& Sarasvathy, S.D. (2010). The coevolution of institutional entrepreneurship: A tale of two theories. Journal of Management, 36(4), 974-1010. http:/ / dx.doi.org/10.1177/0149206309360280

Scott, R.W. (1998). Organizations: Rational, natural, and open system (4th ed.). Upper Saddle River, N.J.: Prentice Hall.

Sihaloho, F.L., \& Halim, A. (September, 2005). Pengaruh faktor-faktor rasional, politik dan kultur organisasi terhadap pemanfaatan informasi kinerja instansi 
pemerintah daerah. Paper presented at Simposium Nasional Akuntansi VIII Solo, Indonesia.

Simons, R. (2000). Performance measurement and control system for implementing strategy: Text and cases. Upper Saddle River, NJ: Prentice Hall.

Sofyani, H., \& Akbar, R. (2013). Hubungan faktor internal institusi dan implementasi sistem akuntabilitas kinerja instansi pemerintah (sakip) di pemerintah daerah. Jurnal Akuntansi dan Keuangan Indonesia, 10(2), 184-205. http://dx.doi.org/10.21002/jaki.2013.10

Speklé R.F., \& Verbeeten, F.H.M. (2009). The use of performance measurement systems in the public sector: Effects on performance. Management Accounting Research, 25(2), 131-146. http:/ / dx.doi.org/10.1016/j.mar.2013.07.004

Talbot, C. (2008). Performance regimes - the institutional context of performance policies. International Journal of Public Administration, 31(14), 15691591. http://dx.doi.org/10.1080/01900690802199437

Tolbert, P.S., \& Zucker, L.G. (1983). Institutional sources of change in the formal structure of organizations: The diffusion of civil service reforms 1880-1935. Administrative Science Quarterly, 28(1), 22-39.

Wijaya, A.H.C., \& Akbar,R. (2013). The influence of information, organizational objective and targets, and external pressure toward the adoption of performance measurement system in public sector. Journal of Indonesian Economy and Business, 28(1), 62-83. http://dx.doi.org/10.22146/jieb.6230

Yaya, R. (2017). Twelve years of scottish school public private partnerships: Are they better value for money? Journal of Public Procurement, 17(2), 187-228. http://dx.doi.org/10.1108/JOPP-17-02-2017-B002

\section{Regulation}

Regulation of The Minister of Administrative and Bureaucratic Reform No. 13/2010 about The Guidance for Evaluation of Accountability Performance of Governmental Institution.

Presidential Instruction (PI) No. 71999 about Performance Measurement Accountability System and Performance Accountability Report for Government's Institutions. 
